\title{
Peningkatan Kemampuan Komunikasi Statistis Siswa pada Pokok Bahasan Ukuran Letak Data melalui Pembelajaran Berbasis Proyek Berbantuan Informasi Komunikasi dan Teknologi (ICT)
}

\author{
${ }^{1}$ Selfira Yoisangaji , ${ }^{2}$ Karman La Nani ${ }^{3}$ In Hi Abdullah \\ 1,2,3 Program Studi Pendidikan Matematika Universitas Khairun
}

\begin{abstract}
ABSTRAK
Penelitian ini bertujuan untuk: 1). mengetahui kemampuan Komunikasi statistis siswa setelah diterapakan model pembelajaran berbasis proyek berbantuan ICT; 2). bagaimana peningkatan kemampuan komunikasi statistis siswa setelah diterapkan model pembelajaran berbasis proyek berbantuan ICT; 3). Penerapan model pembelajaran berbasis proyek berbantuan ICT dapat meningkatkan kemampuan komunikasi statistis siswa SMPN 1 Sulabesi Timur pada pokok pembahasan ukuran letak data. Penerapan penelitian eksperimen ini menggunakan desain one group pretest-posttest, dan menjadikan seluruh siswa kelas VIII-B SMP N I Sulabesi Timur Tahun Ajaran 2019/2020 sebagai sampel penelitian Teknik pengambilan sampel pada penelitian ini yaitu purposive sampling dengan jumlah sampel yaitu 22 siswa. Memperoleh data penelitian ini menggunakan instrument tes untuk mengukur kemampuan komunikasi statistis siswa berbentuk Essay. Data yang diperoleh dianalisis dengan menggunakan statistik deskriptif dan inferensial. Hasil penelitian menunjukkan bahwa : 1) kemampuan komunikasi statistis siswa setelah digunakan model pembelajaran berbasis proyek berbantuan ICT pada pokok pembahasan ukuran letak data 3 siswa dengan persentasi $15 \%$ sangat tinggi, 9 siswa persentasi $30 \%$ kualifikasi tinggi sebanyak 4 siswa dengan persentasi $25 \%$, kualifikasi sedang, sebanyak 3 siswa dengan persentasi $25 \%$ kualifikasi rendah dan kualifikasi sebanyak 3 siswa dengan persentasi 15\% kualifikasi sangat rendah, Berdasarkan hasil kualifikasi dan persentasi siswa secara keseluruhan dapat disimpulkan bahwa penerapan pembelajran berbasis proyek berbantuan ICT dapat meningkatan kemampuan komunikasi statistis siswa dalam mempelajari materi statistika tentang ukuran letak data. Artinya, penerapan pembelajaran berbasis proyek berbantuan ICT dapat meningkatkan kemampuan komunikasi statistis siswa. dan peningkatan kemampuan komunikasi statistis siswa mencapai 0,74 dalam kualifikasi tinggi.
\end{abstract}

Kata Kunci: Model Pembelajran Berbasis Proyek Berbantuan ICT, Kemampuan Komunikasi Statistis Siswa

\section{PENDAHULUAN}

Indonesia termasuk negara dengan tingkat kelahiran yang tinggi di mana generasi muda adalah harapan untuk mengembangkan negara ini dan harapannya juga meraih masa depan melalui pendidikan. Proses pendidikan yang baik akan 
melahirkan generasi penerus bangsa yang cerdas dan kompeten dalam bidangnya, sehingga mendorong kondisi bangsa akan terus mengalami perbaikan.

Undang-undang Republik Indonesia Nomor 20 tahun 2003 tentang sistem pendidikan nasional, pasal 1 ayat (1) disebutkan bahwa pendidikan adalah usaha sadar dan terencana untuk mewujudkan suasana belajar dan proses pembelajaran agar peserta didik secara aktif mengembangkan potensi dirinya untuk memiliki kekuatan spiritual keagamaan, pengendalian diri, kepribadian, kecerdasan, akhlak mulia, serta keterampilan yang diperlukan dirinya, masyarakat, bangsa dan negara (Sisdiknas, 2003: 2)

Matematika dianggap sebagai salah satu pembelajaran yang sulit dan membosankan bagi siswa, karena melibatkan banyak rumus. Menurut Sutriadi (Hyronimus Lado dkk, 2016: 1) mata pelajaran matematika masih dianggap sebagai salah satu mata pelajaran yang sulit dan pada umumnya siswa mempunyai anggapan bahwa matematika merupakan pelajaran yang tidak disenangi. Sutriyadi (Hyronimus Lado dkk, 2016: 1) menyatakan bahwa hal-hal negatif muncul pada diri siswa ketika belajar matematika, berupa alasan cemas. Sehingga guru perlu menyadari bahwa setiap murid tidak selamanya suka matematika. Satu diantara ilmu yang mendasari perkembangan ilmu pengetahuan dan tekhnologi adalah matematika. Depdiknas (dalam Agus Sutriadi dkk, 2017: 142) menyatakan bahwa mata pelajaran matematika pada satuan pendidikan SMP/MTs meliputi aspek-aspek sebagai berikut: bilangan, aljabar, geometri, pengukuran, statistika dan peluang.

Sudjana (Setyo Tri Wahyudi, 2017: 3) statistika adalah pengetahuan yang berhubungan dengan cara-cara pengumpulan data, pengolahan atau penganalisisan yang dilakukan. Statistika mulai dipelajari dari jenjang sekolah menengah pertama (SMP) sampai sekolah menengah atas. Hal ini sejalan dengan pendapat Franklin (Nurul Inayah, 2017: 120-121) yang mengemukakan bahwa selama seperempat abad terakhir, statistika telah menjadi komponen kunci dari kurikulum matematika dalam dunia pendidikan matematika. 
Berdasarkan penjelasan di atas kemampuan komunikasi statistis dapat dikembangkan pada siswa di sekolah menengah. Menurut La Nani (2015: 6) kemampuan komunikasi statistis diperlukan untuk siswa karena siswa dapat memperjelas masalah, memprediksi kejadian suatu masalah berdasarkan karakteristiknya, memperoleh informasi dan kesimpulan yang cepat dari suatu masalah statistika. Hasil kajian Parke (La Nani, 2015: 7) dalam pengajaran yang meminta siswa memiliki pengalaman terbatas dalam berkomunikasi dengan bahasa statistik secara tertulis.

Sebelum peneliti memulai penelitian ini, peneliti melakukan pertemuan terlebih dahulu dengan guru mata pelajaran matematika di SMPN 1 Sulabesi Timur yang nantinya akan menjadi objek penelitian ini, kemudian peneliti melakukan wawancara dengan salah satu guru mata pelajaran matematika yang mengajar di kelas VIII-B semester II. Dari hasil wawancara diketahui bahwa rendahnya prestasi belajar matematika pada materi statistika masih sangat rendah. Siswa jarang sekali mengajukan pertanyaan walaupun guru memancing dengan pertanyaan-pertanyaan yang sekiranya belum dipahami. Kemudian hasil observasi di kelas menunjukkan bahwa pembelajaran matematika selama ini guru masih senantiasa mendominasi kegiatan dan segala inisiatif datang dari guru, sementara siswa sebagai obyek untuk menerima sesuatu yang dianggap penting dan mengahafal materi-materi yang disampaikan oleh guru serta tidak berani mengemukakan ide-ide pada saat pembelajaran berlangsung.

Selain itu, pembelajaran di kelas belum terbiasa dengan belajar secara berkelompok sehingga tidak terjadi komunikasi dalam kelompok maupun antar kelompok. Dari hasil wawancara juga diperoleh informasi bahwa siswa mengalami kesulitan dalam mempelajari matematika, terutama pada materi statistika dengan sub pokok bahasan ukuran letak data (menentukan nilai Desil, Kuartil, Presentil). Hal ini diperkuat dengan hasil tes awal pada siswa kelas VIIIB, tes tersebut dilakukan pada hari senin 18 Februari 2019 di SMP Negeri 1 Sulabei Timur dengan jumlah siswa sebanyak 22 siswa. Dari pengamatan peneliti pada saat siswa menyelesaikan soal mengenai statistika menunjukan 
masih banyak siswa yang bingung dalam proses penyelesaian soal. Pada hasil tes yang diperoleh peneliti yaitu banyak siswa yang masih mengalami kesulitan menjawab soal nomor 2 yakni soal yang mengacu pada kemampuan komunikasi statistis. Berikut salah satu hasil kerja siswa materi ukuran letak data:

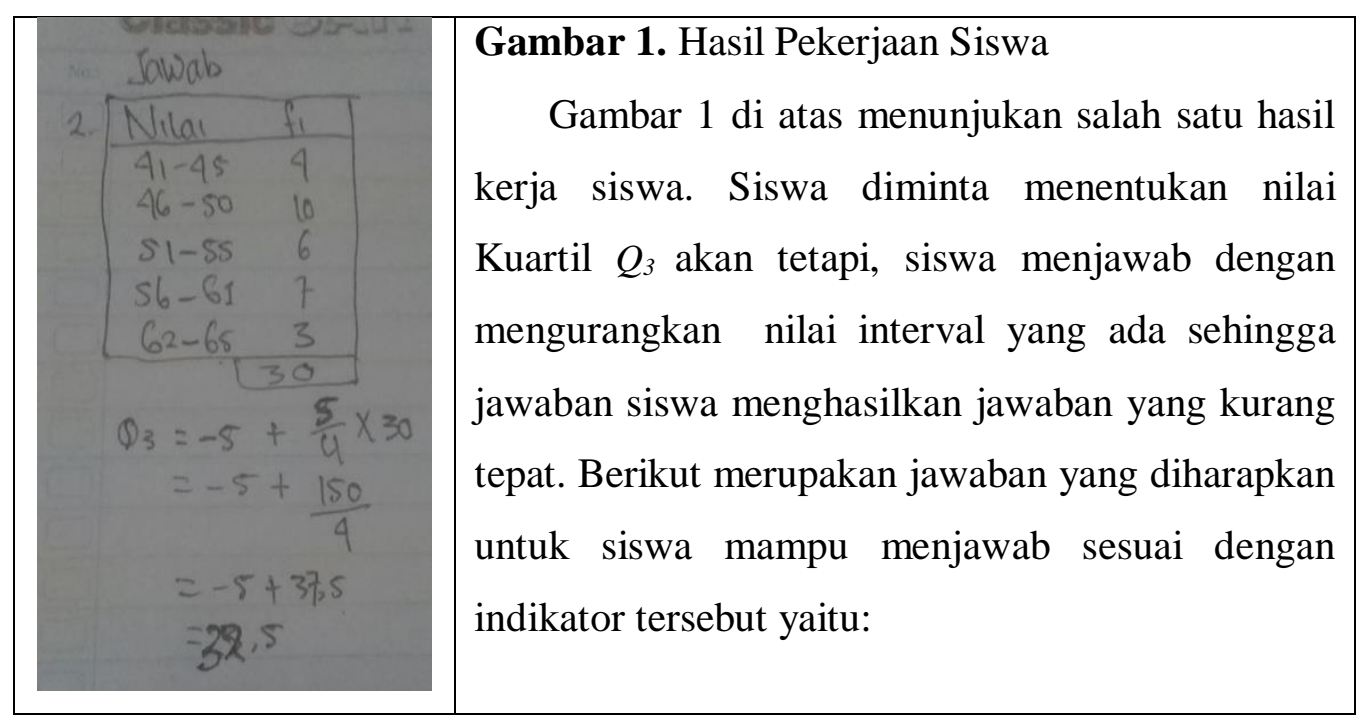

1. Tentukan kuarti $Q_{3}$ dari data nilai UTS Kelas VIII-B SMPN 1 yang disajikan dalam tabel berikut ini!

Tabel 1

Contoh soal

\begin{tabular}{|l|c|}
\hline Nilai & Frekuensi \\
\hline $41-45$ & 4 \\
\hline $46-50$ & 10 \\
\hline $51-55$ & 6 \\
\hline $56-61$ & 7 \\
\hline $62-65$ & 3 \\
\hline
\end{tabular}

Tabel 2

Alternatif penyelesaian

\begin{tabular}{|l|c|c|}
\hline Nilai & Frekuensi & Fk \\
\hline $41-45$ & 4 & 4 \\
\hline $40-50$ & 10 & 14 \\
\hline $51-55$ & 6 & 20 \\
\hline $56-61$ & 7 & 27 \\
\hline $62-65$ & 3 & 30 \\
\hline Jumlah & $\mathbf{3 0}$ & \\
\hline
\end{tabular}




$$
\begin{array}{ll}
Q_{3}=t b i+\left[\frac{\frac{i}{4} \cdot n-F k}{f i}\right] \cdot p & Q_{3}=\mathrm{tbi}+\frac{3}{4} 30=22,5 \\
Q_{3}=55,5+\left[\frac{22,5-20}{7}\right] \cdot 6 & Q_{3}=55,5+\left[\frac{2,5}{7}\right] \cdot 6 \\
Q_{3}=55,5+(0,36) \cdot 6 & Q_{3}=55,5+2,16 \\
Q_{3}=57,6 &
\end{array}
$$

Nilai Kuartil $Q_{3}=57,6$

Jadi, kuartil tiga nilai UTS kelas VIII-B SMP Negeri 1 adalah 57,6

Berdasarkan hasil kerja siswa di atas peneliti menyimpulkan bahwa siswa kelas VIII-B masih kesulitan dalam menyelesaikan masalah statistika yaitu siswa kesulitan dalam menentukan nilai kuartil $Q_{3}$ yang telah disusun pada tabel 1, selain itu kesalahan dalam mentransformasi yaitu siswa memahami apa yang ditanyakan tetapi tidak tepat dalam menjawab. Kesalahan-kesalahan yang dilakukan siswa dalam menjawab soal tersebut disebabkan karena kurangnya pemahaman siswa pada materi yang diajarkan, komunikasi antara siswa tentang materi statistika juga sangat kurang. Menurut indikator yang telah peneliti simpulkan dari beberapa indikator para ahli yaitu; 1) Menyajikan, mengolah, menafsirkan data hasil pengamatan, membuat dugaan, dan menilai informasi statistik, 2) Siswa dapat menghubungkan masalah nyata, gambar,diagram atau tabel ke dalam ide statistik, 3) Siswa dapat menjelaskan ide, situasi, dan relasi statistik secara tertulis, gambar, diagram dan tabel. Sehingga, siswa dituntut untuk mampu berpikir dan menghasilkan jawaban yang sesuai dengan indikator aspek kemampuan komunikasi statistis. Dari jawaban hasil pekerjaan siswa pada Gambar 1 di atas, jika dibandingan dengan jawaban yang diharapkan, maka siswa menjawab soal tidak sesuai dengan indikator aspek yang diharapkan. Dengan keseluruhan informasi di atas maka dapat disimpulkan bahwa terdapat masalah pada aspek kemampuan komunikasi statistis siswa kelas VIII-B. 
Mengatasi permasalahan tersebut, perlu dilakukan perbaikan proses pembelajaran yang sesuai dengan permasalahan belajar. Cara yang dianggap tepat untuk mengatasi masalah belajar siswa di kelas tersebut adalah dengan menggunakan model pembelajaran berbasis proyek berbantuan ICT. Karena dengan model tersebut diharapkan siswa dapat bekerja secara kolaboratif dalam menyelesaikan masalah statistik. Menurut La Nani (2015 : 12) penerapan PBP berbantuan ICT memberikan kesempatan kepada siswa untuk bekerja dengan data statistik yang bersifat otentik, mengkomunikasikan ide-ide statistik, dan memperkenalkan penggunaan software statistik dalam mengelolah dan mengeksplorasi data statistik. Selain itu, menurut penelusuran UNESCO (Ismartoyo dan Yuli Haryati, 2016 :430), ada lima manfaat yang dapat diraih melalui penerapan ICT dalam sistem pembelajaran: (1) mempermudah dan memperluas akses terhadap pendidikan; (2) meningkatkan kesetaraan pendidikan (equiy in education); (3) meningkatkan mutu pembelajaran (the delivery of quality learning and teaching); (4) meningkatkan profesionalisme guru (teachers professional development ); (5) meningkatkan efektifitas dan efisensi manajemen, tata kelola dan administrasi pedidikan.

\section{METODE PENELITIAN}

Penelitian ini dilaksanakan dikelas VIII-B SMP Negeri 1 Sulabesi Timur Kabupaten Kepulawan Sula. Penelitian ini menggunakan One group pretestposttest design (Sugiyono, 2011: 112). Siswa kelas VIII-B terlebih dahulu diberikan pretest (tes awal) tentang kemampuan komunikasi statistis. Setelah diberi tes awal kemudian diberi perlakuan yaitu pembelajaran berbasis proyek berbantuan ICT. Setelah perlakuan selesai, diadakan posttest (tes akhir) untuk mengetahui kemampuan komunikasi statistis siswa. Desain One group pretestposttest ini digambarkan sebagai berikut:

Tabel 5

Desain penelitian One group pretest-posttest design
\begin{tabular}{|c|c|c|c|}
\hline Sampel & Pretest & Treatment & Posttest \\
\hline Kelas VIII-B & $\mathrm{O}_{1}$ & $\mathrm{X}$ & $\mathrm{O}_{2}$ \\
\hline
\end{tabular}


Populasi penelitian ini adalah keseluruhan siswa kelas VIII SMP Negeri 1 Sulabesi Timur tahun pelajaran 2018/2019 yang berjumlah 50 siswa dan terdistribusi pada 2 kelas. Sampel dalam penelitian ini yaitu siswa kelas VIII-B SMPN 1 Sulabesi Timur tahun ajaran 2018/2019 dengan jumlah siswa sebanyak 22 siswa diantaranya 10 siswa laki-laki dan 12 siswa perempuan. Teknik pengambilan sampel yang digunakan dalam penelitian ini adalah simple random sampling. Variabel penelitian pada dasarnya adalah segala sesuatu yang berbentuk apa saja yang ditetapkan oleh peneliti untuk dipelajari sehingga diperoleh informasi tentang hal tersebut, kemudian ditarik kesimpulannya (sugiyono, 2011: 63).Penelitian ini terdiri atas dua variabel yaitu, Variabel bebas (independent variabel)dan Variabel terikat (dependent variabel). Variabel bebas pada penelitian ini adalah pembelajaran menggunakan model pembelajaran berbasis proyek berbantuan ICT kemudian Variabel Terikat adalah kemampuan komunikasi statistis siswa SMP Negeri 1 Sulabesi Timur.

Data penelitian ini diperoleh melalui tekhnik tes dan nontes. Tes terdiri dari pretest dan posttes, sedangkan nontes yaitu observasi aktivitas guru dan aktivitas siswa serta wawancara siswa berdasarkan hasil kerjanya terhadap instrumen tes yang diberikan.

Instrumen pengumpulan data pada penelitian ini adalah instrumen tes, pedoman observasi dan pedoman wawancara. Soal tes yang diberikan adalah soal uraian, pada materi ukuran letak data sebanyak 3 soal. Soal-soal tersebut dibuat mencakup tiga indikator kemampuan komunikasi statistis. instrumen pretest diberikan untuk mengukur kemampuan siswa terhadap materi yang akan diajarkan, sedangkan posttest diberikan untuk mengukur kemampuan komunikasi statistis siswa setelah mendapat perlakuan pembelajaran menggunakan model pembelajaran berbasis proyek berbantuan ICT.

Instrumen pretest dan postest sebelum diberikan kepada siswa sebagai sampel terlebih dahulu divalidasi oleh pembimbing dan beberapa validator. Validasi dimaksudkan untuk mengetahui kesesuaian isi instrumen dengan materi, model 
dan indikator kemampuan yang diukur. Mengetahui bahwa instrumen yang disusun telah memenuhi syarat maka dilakukan uji validitas empiris instrumen dan uji reliabilitas instrumen.

Validitas konstruk merupakan derajat yang menunjukkan bahwa suatu instrumen dapat mengukur sebuah konstruk sementara (Sukardi, dalam Ratna Amirudin, 2018: 31). Menghitung koefisien validitas dilakukan dengan rumus korelasi product moment. Menghitung koefisien validitas instrumen yang telah disusun berdasarkan data hasil ujicoba menggunakan rumus korelasi product moment angka kasar (La Nani, 2015: 81).

$$
r_{\mathrm{XY}}=\frac{\mathrm{n} \Sigma \mathrm{XY}-(\Sigma \mathrm{X})(\Sigma \mathrm{Y})}{\sqrt{\left(\mathrm{n} \Sigma \mathrm{X}^{2}-(\Sigma \mathrm{X})^{2}\right)\left(\mathrm{n} \Sigma \mathrm{Y}^{2}-(\Sigma \mathrm{Y})^{2}\right)}}
$$

Keterangan :

$r_{x y}=$ Koefisien korelasi antara variabel $\mathrm{X}$ dan $\mathrm{Y} ; \mathrm{X}=$ Skor tiap butir soal

$\mathrm{Y} \quad=$ Skor Total; $(\mathrm{XY})=$ Jumlah seluruh skor $\mathrm{X}$ dikalikan $\mathrm{Y} ; \mathrm{N}=$ Jumlah

Responden.

Hasil perhitungan kemudian dikonsultasikan dengan harga kritis $\mathrm{r}$ product moment dengan ketentuan $r_{x y}$ lebih dari $r_{\text {tabel }}$ maka soal dikatakan valid dengan tarafsignifikansi 3\%. Dengan memperhatikan nilai $\mathrm{r}_{\text {tabel }}$ dan membandingkannya

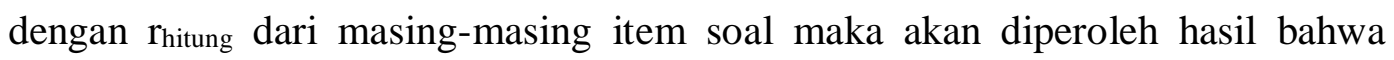
semua item soal valid dan cukup baik untuk digunakan sebagai alat pengumpul data.

Uji reliabilitas instrumen adalah ketepatan atau keajegan dalam menilai apa yang dinilainya. Artinya, kapanpun alat penilaian tersebut digunakan akan memberikan hasil yang relatif sama (Sudjana dalam Zulkifli, 2009: 93). Berikut adalah rumus koefisien alfa Cronbach:

$$
r_{11}=\left(\frac{\mathrm{k}}{\mathrm{k}-1}\right)\left(1-\frac{\Sigma \mathrm{S}_{\mathrm{b}^{2}}}{\mathrm{~S}_{\mathrm{t}^{2}}}\right)
$$

Sumber: Arikunto (dalam La Nani, 2015: 82)

Dengan:

$r_{11}=$ Reliabilitas Instrument; $\mathrm{k}=$ Jumlah butir; $\Sigma \mathrm{S}_{\mathrm{b}^{2}}=$ Jumlah varians butir $\mathrm{S}_{\mathrm{t}^{2}} \quad=$ Jumlah varians total 
Teknik analisis data yang digunakan dalam penelitian ini yaitu teknik analisis data secara kuantitatif. Data kuantitatif adalah data yang berbentuk angka atau data kualitatif yang diangkakan/scoring (Sugiyono, 2011: 6). Data yang terkumpul kemudian dianalisis. Analisis diarahkan untuk menjawab rumusan masalah dan hipotesis penelitian yang diajukan. Data kuantitatif dianalisis menggunakan statistik. Statistik yang digunakan berupa statistik deskriptif dan inferensial (Sugiyono, 2011: 54).

Tbel Uji normalitas statistik Shapiro-Wilk yang dihitung menggunakan SPSS 23 Shapiro-Wilk

Ho: Data berasal dari populasi yang berdistribusi normal

$\mathrm{H} 1$ : Data berasal dari populasi yang tidak berdistribusi normal

Kriteria pengujian yang digunakan untuk mengatur normalitas data dalam pengujian ini adalah Ho dierima apabila nilai sig > tingkat alpha yang ditetapkan yaitu $5 \%$

Menjawab rumusan masalah pertama, akan digunakan hipotesis uji sebagai berikut:

$H_{O}: \mu \leq \mu_{0}=$ Tidak terdapat peningkatan kemampuan komunikasi statistis siswa setelah diterapkan model pembelajaran berbasis proyek berbantuan ICT.

$H_{1}: \mu>\mu_{0}=$ Terdapat peningkatan kemampuan komunikasi statistis siswa setalah diterapkan model pembelajaran berbasis proyek berbantuan ICT.

Keterangan:

$\mu_{0} \quad=$ Kriteria Ketuntasan Minimal $(\mathrm{KKM}=70)$

$\mu=$ Rata-Rata Kemampuan komunikasi statistis siswa setelah diberikan perlakuan.

Dalam melakukan $t$-test syaratnya data harus berdistribusi normal. Rumust-test one-sample (Sugiyono, 2011: 236) sebagai berikut:

$$
t=\frac{\bar{x}-\mu_{o}}{\frac{S}{\sqrt{n}}}
$$


Uji hipotesis digunakan untuk mengetahui apakah terdapat peningkatan pada kemampuan komunikasi statistis siswa setelah diterapkan pembelajaran berbasis proyek berbantuan ICT. Berdasarkan hasil uji normalitas yang telah dilakukan, data sebelum dan sesudah penerapan model PBP berbantuan ICT berdistribusi normal, maka statistik uji yang digunakan adalah statistik parametric, yaitu dengan menggunakan statsitik uji hipotesis Paired Sample t-test. Pengujian menggunakan bantuan program SPSS 23 For Windows dengan melihat nilai signifikansi pada uji Paired Sample T-test. Data statistik uji hipotesis Paired Sample T-test, secara ringkas dijelaskan pada tabel 17 berikut ini:

Tabel 17

Analisis Data Hasil Uji Hipotesis

\begin{tabular}{|l|l|}
\hline Pembelajaran & Sig (2tailed) \\
\hline Sebelum dan Sesudah & $\mathbf{0 , 0 0 0}$ \\
\hline
\end{tabular}

Hipotesis:

$\mathrm{H}_{0} \quad$ : Tidak terdapat peningkatan kemampuan komunikasi statistis siswa pada materi ukuran letak data

$\mathrm{H}_{1} \quad$ : Terdapat peningkatan kemampuan komunikasi statistis siswa pada materi ukuran letak data

\section{HASIL PENELITIAN DAN PEMBAHASAN}

\section{Terdapat Peningkatan Kemampuan Komunikasi Statistis Siswa Setelah Diterapkan Pembelajran Berbasis Proyek Berbantuan ICT.}

Berdasarkan analisis hasil penelitian menggunakan program SPSS 23 For Windows, diperoleh bahwa nilai signifikansi kurang dari 0,05 (sig.<0,05) sehingga tolak $\mathrm{H}_{0}$ dan terima $\mathrm{H}_{1}$. Oleh karena itu, maka dapat disimpulkan bahwa terdapat peningkatan komunikasi statistis siswa setelah diterapkannya pembelajaran berbasis proyek berbatuan ICT. Hal ini dapat dilihat pada peningkatan tiap Indikator komunikasi statistis, yaitu menjelaskan ide, secara tertulis, menghubungkan masalah nyata ke dalam ide statistik, menyajikan dan mengelolah data. Peningkatan kemampuan komunikasi statistis siswa dapat juga dilihat pada nilai rata-rata diperoleh dimana nilai sebelum penerapan PBP 
berbantuan ICT yaitu 19.09 kemudian sesudah diterapkan PBP berbantuan ICT nilai rata-rata menunjukkan meningkatan menjadi 79,18.

\section{Kualifikasi Peningkatan KKS Siswa Setelah dan Sesudah Diterapkan Pembelajaran Berbasis Proyek (PBP) Berbantuan ICT}

Peningkatan kemampuan komunikasi staatistis siswa pada materi ukuran letak data.

\section{Tabel 14}

Peningkatan Kemampuan Komunikasi Statistis Perindividu

\begin{tabular}{|c|c|l|l|}
\hline Interval Gain Internormalisasi & Jumlah Siswa & Persen & Interpertasi \\
\hline$(<g>)>0,7$ & 12 & $54,54 \%$ & Tinggi \\
\hline $0,3<(<g>) \leq 0,7$ & 10 & $45,45 \%$ & Sedang \\
\hline & 22 & $100 \%$ & Sedang \\
\hline
\end{tabular}

Berdasarkan data pada tabel diatas menunjukkan nilai rata-rata tes sebelum (pretest) dan setelah pembelajaran berturut-turut adalah 19,09 dan 79,18 Rata-rata hasil kemampuan komunikasi statistis siswa pada nilai (posttest) telah memenuhi standar ketuntasan minimal, sehingga besar peningkatannya dapat dilihat pada selisi nilai rata-ratanya yakni 19,09. Kemudian dari hasil komputasi diperoleh peningkatan kemampuan komunikasi statistis siswa dengan menggunkan rumus gain ternormalisasi atau Normalized Gain (N-Gain) yaitu 0,74 dengan interprestasi tinggi.

3. Peningkatan Kemampuan Komunikasi Statistis Siswa Setelah Diterapkan Pembelajaran Berbasisi Proyek Berbantaun ICT Pada Materi Ukuran Letak Data

Tabel 15

Peningkatan Kemampuan Komunikasi Statistis Siswa Setelah Diterapkan PBP Berbantuan ICT

\begin{tabular}{|c|c|c|c|}
\hline Rata-Rata Pretest & Rata-Rata Posttest & N-Gain & Interpretasi \\
\hline 19,09 & $\mathbf{7 9 , 1 8}$ & $\mathbf{0 , 7 4}$ & tinggi \\
\hline
\end{tabular}


Berdasarkan data yang disajikan pada tabel 15 dapat dijelaskan bahwa Rata-rata sebelum penerapan PBP berbantuan ICT yaitu 19,09 lebih rendah dari pada Rata-rata sesudah penerapan PBP berbantuan ICT yaitu 79,18, dengan nilai $\mathrm{N}-$ Gain $=0,74$. Hal ini menunjukkan kategori interpretasi tinggi, maka dapat disimpulkan bahwa terjadi peningkatan kemampuan komunikasi statistis siswa pada materi statistika tentang ukuran letak data setelah diterapkannya model pembelajran berbasis proyek berbantuan ICT.

\section{Peningkatan Kemampuan Komunikasi Statistis Siswa Setelah diterapkan Model Pembelajaran Berbasis Proyek Berbantuan ICT}

Penelitian ini bertujuan untuk mengetahui apakah terdapat peningkatan kemampuan komunikasi statistis siswa setelah diterapkan model pembelajran berbasis proyek berbantuan ICT pada materi ukuran letak data. Salah satu pengujian persyaratannya yaitu uji normalitas. Uji normalitas dilakukan dengan tujuan untuk mengetahui apakah data yang diuji berdistribusi nornmal atau tidak berdistribusi normal. Data distribusi normal digunakan uji hipotesis paired sampel T-test sedangkan dat yang tidak berdistribusi normal di gunakan uji wilcoxon.

\section{a. Uji Normalitas}

Uji normalitas dilakukan dengan menggunakan bantuan program SPSS 23 For Windows. Kriteria pengujian diterima $\mathrm{H}_{0}$ jika nilai signifikansi Shapiro-Wilk yang diperoleh lebih dari taraf signifikansi $\propto=0,05$ untuk nilai lainnya $\mathrm{H}_{0}$ ditolak. Hasil uji normalitas data sebelum dan sesudah penerapan model PBP berbantuan ICT secara lengkap, ringkasan dijelaskan pada tabel 16 berikut ini:

\section{Tabel 16}

Hasil Uji Normalitas Data KKS Siswa

Sebelum Dan Sesudah PBP berbantuan ICT Pada Materi Ukuran Letak

\begin{tabular}{|c|c|c|c|c|}
\hline Pembelajaran & N & SW & Sig & $\mathbf{H}_{\mathbf{0}}$ \\
\hline Sebelum & 22 & $\mathbf{0 , 9 2 8}$ & $\mathbf{0 , 1 4 1}$ & Terima \\
\hline Sesudah & 22 & $\mathbf{0 , 9 4 7}$ & $\mathbf{0 , 3 2 2}$ & Terima \\
\hline
\end{tabular}

Hasil uji normalitas yang disajikan pada tabel 16 dapat dijelaskan bahwa data peningkatan sebelum pembelajran berbasis proyek berbanuan ICT doperoleh nilai signifikansi lebih dari $\propto=0,05$ yaitu 0,141 sehingga $\mathrm{H}_{0}$ diterima. Berarti 
data tersebut secara signifikansi berdistribusi normal, dan data sesudah pembelajaran berbasis proyek berbantuan ICT diperoleh nilai signifikansi lebih dari $\propto=0,05$ yaitu 0,322 sehingga $\mathrm{H}_{0}$ diterima. Berarti, data tersebut secara signifikansi adalah berdistribusi normal, dilanjutkan uji hipotesis. 


\section{KESIMPULAN}

Berdasarkan hasil penelitian dan pembahasan dapat diajukan beberapa kesimpulan berikut:

1. Kemampuan komuniksi statistis siswa kelas VIII-B SMPN 1 Sulabesi Timur kabupaten kepulauan sula setelah diterapkan pembelajaran barbasis proyek berbantuan ICT sangat baik sebanyak 3 siswa dengan rata-rata 0,91 persentase $15 \%$, kualifikasi tinggi sebanyak 9 siswa dengan rata-rata 0,89 persentase $30 \%$, kualifikasi baik sebanyak 4 siswa dengan rata-rata 0,67 persentase $25 \%$, kualifikasi cukup sebanyak 3 siswa dengan rata-rata 0,65 persentase. $15 \%$ kualifikasi kurang 3 siswa dengan rata-rata 0,53 persentase $15 \%$ kualifikasi buruk.

2. Peningkatan kemampuan komunikasi statistis siswa kelas VIII-B SMPN 1 Sulabesi Timur Kabupaten Kepulauan Sula setelah diterapkan pembelajaran berbasis proyek berbantuan ICT secara individu diperoleh 12 siswa dengan besar persentase $54,54 \%$ dalam kategori kemampuan sangat baik, 10 siswa dengan persentase $45,45 \%$ dalam interprestasi kemampuan baik

3. Penerapan pembelajaran PBP berbantuan ICT secara singnifikan dapat meningkatkan kemampuan statistik siswa SMPN 1 Sulabesi Timur pada materi ukuran letak data 


\section{DAFTAR PUSTAKA}

Adawiah, R., Side Side, S 2014 Pengaruh Pembelajaran Berbasis Proyek Dalam Model Pembelajaran Berbasis Proyek Terhadap Hasil Belajar Peserta Didik Kelas MS SMAN 3 Lalu maros (Studi Pada Materi Pokok) Keseimbangan Kimia). Jurnal Chemica, Vol 15, No 2

Depdiknas. 2016. Peratssuran Mentri Pendidikan dan Kebudayaan Nomor 21 Tahun 2016 Tentang Standar Isi Pendidikan Dasar dan Menengah

Franklin, C., \& Garfield, J. (2006). The Guidelines for Assessment and Instruction in Statistics Education (GAISE) project: Developing statistics education guidelines for pre $\mathrm{K}-12$ and college courses. In G.F. Burrill, (Ed.), Thinking and reasoning about data and chance: Sixty-eighth NCTM Yearbook (pp. 345-375). Reston, VA: National Council of Teachers of Mathematics.

Hadiyanto. 2017. Kemampuan Komunikasi Matematis Dalam Pembelajaran Matematika. Jurnal AdMathEdu, Vol.7 No.1

Lanani, K. (2015). Peningkatan kemampuan penelaran statistis, komunikasih statistis dan Academic Help-seeking mahasiswa melalui pembelajaran berbasis proyek berbantuan ICT 